\title{
Changes in policy for publishing manuscripts in Neurology
}

\author{
Robert C. Griggs, MD
}

Our Editorial Board has approved new policies for Neurology regarding: (1) expedited publications; (2) structured abstracts; (3) international reviewers; and (4) on-line publication. The accompanying editorial by Karl Kieburtz, Associate Editor of Neurology, deals with policies on supplements and reporting clinical trials.

Expedited publication specifications. We have established an Expedited Publication section of the journal, modeled on those of other journals that compete successfully for important clinical science. This section of the journal will have the following specifications:

- Expedited publications must not exceed four printed pages in Neurology, including all figures, figure legends, tables, and references. This is equivalent to 24,000 characters (one space is one character as is one letter). Each table and figure within a manuscript decreases the space available for text; an accurate estimate of the character equivalence of tables and figures can be made by looking at any issue of the journal. The character count is the definitive limiting factor.

- Expedited manuscripts will be reviewed for both (1) the importance of the research and (2) the need for accelerated publication.

- Manuscripts not accepted for expedited publication will be rejected.

- Manuscripts requiring major revisions will not be expedited.

It is essential that authors be selective in requesting expedited publication. Papers accepted for this section will have to vault a higher hurdle by being both high priority and timely. Manuscripts rejected for expedited publication will not be considered for routine publication. The review process will be as rapid as possible (our goal is 7 to 10 days).

We are continuing to work on reducing the delay from the submission of manuscripts to their acceptance. This process places increased demands on our reviewers. We are extremely grateful for their responsiveness. Reviews are now faxed to us.
Structured abstracts. Effective immediately, Neurology requires that all original articles submitted include a structured abstract that lists: Objective, Background, Design or Methods (or both), Results, and Conclusions. "Brief Communications," "Clinical/ Scientific Notes," papers dealing with history of neurology, and "Contemporary Issues" papers will not be required to have structured abstracts. Most "Views and Reviews" should. Articles currently under review will not be required to comply with this new policy. If the style of an article precludes the sensible development of a structured abstract, authors should indicate why and request an exception in the transmittal letter.

International reviewers. An ever-increasing number of outstanding manuscripts from outside the United States are being received and published by Neurology. Neurology has begun to seek the help and expertise of reviewers in countries other than the United States and Canada. Suitable manuscripts are handled by fax and all others by courier service. We expect to appoint a small number of clinical neuroscientists from overseas to the Neurology Editorial Board. Once we are certain that confidentiality can be assured, manuscripts will be sent electronically to reviewers who are able to receive and review in this manner.

On-line publishing. The Neurology table of contents is up on the American Academy of Neurology web site 2 to 3 weeks in advance of the journal's publication. This autumn, Neurology will become available on-line through Ovid Technologies' Biomedical Collection. Ovid is a service available through major libraries and other institutions. Back issues of Neurology (beginning in 1995) will also be made available. MD Consult (a subscription service for primary care physicians) will also provide the journal to subscribers. We anticipate that these steps will accelerate the process of making the journal electronically available to the readership of Neurology. 


\title{
Neurology
}

\author{
Changes in policy for publishing manuscripts in Neurology \\ Robert C. Griggs \\ Neurology 1997;49;1 \\ DOI 10.1212/WNL.49.1.1
}

This information is current as of July 1, 1997

\section{Updated Information \& \\ Services}

Citations

Permissions \& Licensing

Reprints including high resolution figures, can be found at:

http://n.neurology.org/content/49/1/1.full

This article has been cited by 85 HighWire-hosted articles: http://n.neurology.org/content/49/1/1.full\#\#otherarticles

Information about reproducing this article in parts (figures,tables) or in its entirety can be found online at:

http://www.neurology.org/about/about_the_journal\#permissions

Information about ordering reprints can be found online:

http://n.neurology.org/subscribers/advertise

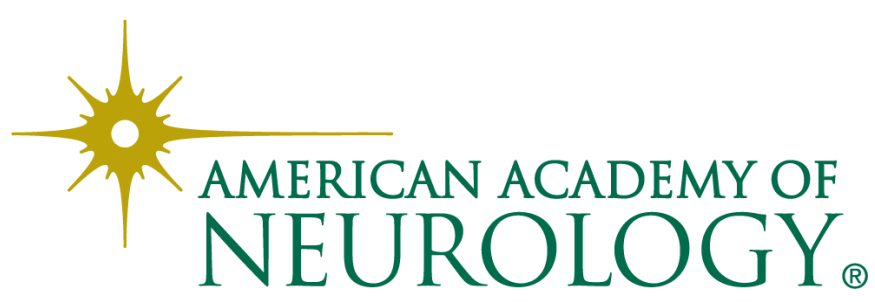

